\title{
PEMALSUAN TANDATANGAN DALAM PRINSIP PEMIDAAN \\ HUKUM DI INDONESIA
}

MOH. ZAINOL ARIEF

Dosen Fakultas Hukum Universitas Wiraraja Sumenep

sobarchamim@gmail.com

\begin{abstract}
ABSTRAK
Pidana dan pemidanaan dalam ilmu pengetahuan hukum pidana tidak begitu banyak yang memberikan sorotan, dan bahkan terkesan sebagai "anak tiri". Ilmu pengetahuan hukum pidana yang dikembangkan dewasa ini masih banyak membicarakan masalah-masalah dogmatik hukum pidana dari pada sanksi pidana. Pembahasan tentang sanksi pidana yang bersifat memperkokoh norma hukum pidana belum banyak dilakukan, sehingga pembahasan seluruh isi hukum pidana dirasakan masih belum serasi.Tujuan dalam penelitian ini, yaitu : untuk mengkaji dan menganalisa Prinsip Pemidaan Dalam Sistem Hukum Di Indonesia. Metode pendekatan masalah yang digunakan oleh peneliti dengan cara menggunakan yuridis normatif dimana mengkaji peraturan perundang-undangan mengenai orientasi prinsip pemidanaan sistem sistem hukum di Indonesia.
\end{abstract}

Kata kunci : Pemalsuan Tandatangan, Sistem Hukum Indonesia.

\section{A. PENDAHULUAN}

Dalam pengertian substantif, hukum pidana dihadapkan pada tiga persoalan pokok, yaitu menyangkut masalah perbuatan pidana (tindak pidana/delik), pertanggungjawaban pidana serta masalah pidana dan pemidanaan. Dari ketiga persoalan tersebut, maka yang mempunyai relevansi dengan tulisan ini adalah menyangkut masalah pidana dan pemidanaan.

Bahwa ancaman pidana yang dicantumkan pada tiap-tiap delik pada hakekatnya adalah menggambarkan ketercelaan dan keseriusan perbuatan yang bersangkutan. Artinya, bahwa suatu perbuatan yang diancamkan dengan pidana penjara 2 tahun akan lebih atau setidaktidaknya dipandang lebih tercela dibandingkan dengan perbuatan lain yang diancamkan dengan pidana penjara 1 tahun, misalnya. Demikian pula halnya dengan ancaman pidana mati atau ancaman pidana seumur hidup.

Di dalam Pasal 10 KUHP diatur tentang jenis-jenis pidana, yaitu yang terdiri dari pidana pokok (pidana mati, pidana penjara, pidana kurungan, pidana denda, dan pidana tutupan), dan pidana tambahan yang terdiri dari: pencabutan hak-hak tertentu dan perampasan barangbarang tertentu serta pengumuman putusan hakim.

Lebih lanjut berkenaan dengan pidana penjara dalam Pasal 12 KUHP ditegaskan:

1) Pidana penjara adalah seumur hidup atau selama waktu tertentu 
2) Pidana penjara selama waktu tertentu paling pendek adalah satu hari dan paling lama lima belas tahun berturutturut

3) Pidana penjara selama waktu tertentu boleh dijatuhkan untuk dua puluh tahun berturut-turut dalam hal kejahatan yang pidananya hakim boleh memilih antara pidana mati, pidana seumur hidup dan pidana penjara selama waktu tertentu, begitu juga dalam hal batas lima belas tahun dapat dilampaui karena perbarengan (concursus), pengulangan (residive) atau karena ditentukan dalam Pasal 52 dan 52a (L.N. 1958 no. 127).

Pidana penjara merupakan salah satu bentuk pidana berupa kehilangan kemerdekaan. Bentuk pidana penjara pada dewasa ini merupakan bentuk utama dan umum dari pidana kehilangan kemerdekaan. Dahulu kala, pidana penjara tidak dikenal di Indonesia (hukum adat), yang dikenal ialah pidana pembuangan.

Pidana dan pemidanaan dalam ilmu pengetahuan hukum pidana tidak begitu banyak yang memberikan sorotan, dan bahkan terkesan sebagai "anak tiri”. Ilmu pengetahuan hukum pidana yang dikembangkan dewasa ini masih banyak membicarakan masalah-masalah dogmatik hukum pidana dari pada sanksi pidana. Pembahasan tentang sanksi pidana yang bersifat memperkokoh norma hukum pidana belum banyak dilakukan, sehingga pembahasan seluruh isi hukum pidana dirasakan masih belum serasi.

Adapaun yang menjadi rumusan masalah dalam tulisan ini adalah bagaimana Orientasi Prinsip Pemidaan Dalam Sistem Hukum Di Indonesia?

Tujuan dalam penelitian ini, yaitu : untuk mengkaji dan menganalisa Prinsip Pemidaan Dalam Sistem Hukum Di Indonesia.

Metode pendekatan masalah yang digunakan oleh peneliti dengan cara menggunakan yuridis normatif dimana mengkaji peraturan perundang-undangan mengenai orientasi prinsip pemidanaan sistem sistem hukum di Indonesia.

\section{B. PEMBAHASAN}

Masalah pidana dianggap merupakan suatu bidang yang tak banyak diketahui, sehingga pembahasan tentang ilmu hukum pidana yang menyoroti pidana pada umumnya dan pidana penjara pada khususnya kurang mendapat perhatian. Selama ini yang banyak dipersoalkan dalam ilmu hukum pidana terletak di bidang asas-asas hukum pidana yang menyangkut perbuatan pidana dan pertanggung jawaban pidana.

Pidana penjara yang merampas kemerdekaan manusia patut sekali mendapat perhatian. Di satu pihak terdapat persentase yang tinggi dari putusan hakim pengadilan yang menjatuhkan pidana penjara kepada terdakwa, di pihak lain 
dalam pelaksanaannya hal itu menyangkut martabat manusia yang menjadi narapidana serta kedudukannya sebagai warga negara atau penduduk Negara Republik Indonesia.

Fungsi pidana sebagai salah satu alat unt uk "menghadapi" kejahatan melalui rentetan sejarah yang panjang mengalami perubahan-perubahan dan perkembangan, dari satu cara yang bersifat "pembalasan" terhadap orang-orang yang melakukan kejahatan berubah menjadi alat untuk melindungi individu dari gangguan individu lainnya dalam masyarakat, dan perlindungan masyarakat dari gangguan kejahatan, terus berubah dan berkembang ke arah fungsi pidana (khususnya pidana penjara) sebagai wadah pembinaan narapidana untuk pengembalian ke dalam masyarakat.

Dalam rangka ini, bertolak dari ide dasar Sahardjo, SH., pada saat menerima gelar Doktor Honoris Causa pada Tanggal 5 Juli 1963, mengemukakan ide pembaharuan sistem pidana penjara. Menurut Sahardjo, tujuan dari pidana penjara adalah, di samping menimbulkan rasa derita kepada terpidana karena hilangnya kemerdekaan bergerak, membimbing terpidana agar bertobat serta mendidiknya agar ia menjadi seorang anggota masyarakat sosialis Indonesia yang berguna. Tujuan pemenjaraan yang demikian itu disebutnya dengan pemasyarakatan.
Dari rumusan tujuan pemidanaan tersebut di atas, dapat dinyatakan bahwa ide Sahardjo menganut sistem campuran penjeraan (deterrent) dan reformasi terpidana. Tujuannya ada dua, yaitu mengayomi masyarakat dari perbuatan jahat, dan membimbing terpidana sehingga dapat kembali menjadi anggota masyarakat yang berguna.

Ide Sahardjo tersebut selanjutnya dijabarkan dalam konperensi Direktur Penjara seluruh Indonesia pada tanggal 27 April 1964 di Lembang, Bandung. Pada Konperensi itulah dimulai tekad untuk memperbaiki sistem pembinaan narapidana dan anak didik. Sistem lama yang berdasarkan Reglement Kepejaraan warisan kolonial Belanda diganti dengan sistem pembinaan yang berlandaskan Pancasila dan UUD 1945 yaitu dengan dikeluarkannya Undang-Undang Nomor 12 tahun 1995 Tentang Pemasyarakatan.

Pidana merupakan suatu alat atau sarana untuk mencapai tujuan. Pidana bukan merupakan tujuan, dan memang tidak mungkin menjadi tujuan. Yang mempunyai tujuan disini justru adalah pemidanaan itu sendiri. Tujuan pemidanaan yang berkembang dari dahulu sampai sekarang telah semakin munjurus ke arah yang lebih rasional. Tujuan pemidanaan yang paling tua adalah pembalasan (revenge) atau untuk tujuan memuaskan pihak yang dirugikan atau yang menjadi korban kejahatan. Hal ini 
bersifat primitif, tetapi kadang-kadang masih terasa pengaruhnya pada zaman modern ini. Unsur-unsur primitif dari hukum pidana yang demikian itu sukar untuk dihilangkan. Tujuan yang juga dipandang kuno yaitu penghapusan dosa (expiation) atau retribusi (retribution), yaitu melepaskan pelanggar hukum dari perbuatan jahat atau menciptakan balans antara yang hak dan yang bathil.

$$
\text { Berkaitan dengan tujuan }
$$

pemidanaan, paling tidak terdapat 3 golongan utama teori untuk membenarkan penjatuhan pidana, yaitu:

1. teori absolut atau teori pembalasan (vergeldingstheorien).

2. teori relatif atau teori tujuan (doeltheorien).

3. Teori penggabunagan (verenigingstheorien).

Teori yang pertama muncul pada akhir abad ke 18, dianut antara lain oleh Immanuel Kant, Hegel, Herbart, Stahl, Leo Polak dan beberapa sarjana yang mendasarkan teorinya pada filsafat Khatolik.Teori pembalasan mengatakan, bahwa pemidanaan tidaklah bertujuan untuk hal-hal yang praktis, seperti memperbaiki penjahat.

\begin{tabular}{lcr}
\multicolumn{1}{c}{ Kejahatan } & itu sendirilah & yang \\
mengandung & unsur-unsur & untuk \\
dijatuhkannya pidana. Pidana & secara \\
mutlak ada, karena dilakukannya & \\
kejahatan. Tidaklah perlu untuk \\
memikirkan manfaat penjatuhan pidana
\end{tabular}

itu. Setiap kejahatan berakibat dijatuhkannya pidana pada si pelaku.

Oleh karena itulah maka teori ini disebut teori absolut. Pidana merupakan tuntutan mutlak, bukan hanya sesuatu yang perlu dijatuhkan tetapi menjadi suatu keharusan. Hakekat suatu pemidanaan adalah pembalasan.

Teori tentang tujuan pemidanaan yang kedua yaitu teori relatif. Teori ini mencari dasar hukum pidana dalam penyelenggaranaan tertib masyarakat dan akibatnya yaitu tujuan pemidanaan untuk prevensi terjadinya kejahatan. Wujud pidana ini berbeda-beda menakutkan, memperbaiki atau membinasakan. Lalu dibedakan antara prevensi umum dan prevensi khusus. Prevensi umum menghendaki agar orang-orang lain pada umumnya tidak melakukan delik (Andi Hamzah, 1986:47).

Bentuk tertua dari prevensi umum dipraktekkan sampai revolusi Perancis. Prevensi umum dilakukan dengan menakutkan orang-orang lain dengan jalan pelaksanaan pidana yang dipertontonkan di depan khalayak ramai. Kadang-kadang pelaksanaan pidana yang telah diputuskan itu dipertontonkan di depan umum dengan sangat ganasnya, dengan tujuan supaya anggota masyarakat ngeri melihatnya. Untuk ini terkenal suatu adagium Latin yang berbunyi, "nemo prudens punit, quia peccatum, sed net peccetur" (supaya khlayak ramai betul-betul takut melakukan 
kejahatan, maka perlu pidana yang ganas dan pelaksanaannya di depan umum).

Pada zaman Aufklarung, abad ke 18, pelaksanaan pidana yang ganas ini ditentang secara besar-besaran. Terutama oleh Beccaria dalam bukunya Dei Delliti e delle pene. Keberatan terhadap prevensi umum ini ialah diperguanakannya penderitaan orang lain untuk maksud prevensi umum. Bahkan ada kemungkinan orang yang tidak bersalah dipidana, dipergunakan untuk maksud prevensi umum tersebut.

Sebaliknya, prevensi khusus, yang dianut oleh van Hamel (Belanda) dan von Lizt (Jerman) mengatakan, bahwa tujuan prevensi khusus ialah mencegah niat buruk pelaku (dader) bertujuan mencegah bakal pelanggar mengulangi perbuatannya atau mencegah bakal pelanggar melaksanakan perbuatan jahat yang direncanakannya.

Ridwan Halim, (2005:17). Maksud prevensi khusus dari suatu pemidanaan ialah :

1. Bahwa pidana harus memuat suatu unsur menakutkan supaya mencegah penjahat yang mempunyai kesempatan untuk tidak melaksanakan niat buruknya

2. Dengan pemidanaan harus mempunyai unsur memperbaiki terpidana

3. Pemidanaan mempunyai unsur membinasakan penjahat yang tidak mungkin diperbaiki lagi
4. Tujuan satu-satunya suatu pemidanaan adalah mempertahankan tata tertib hukum.

Kemudian teori gabungan antara pembalasan dan prevensi terdapat beberapa variasi. Ada yang menitikberatkan pada pembalasan, dan ada pula yang menghendaki unsur pembalasan dan prevensi seimbang.

Yang pertama, yaitu menitik beratkan pada unsur pembalasan yang antara lain dianut oleh Pompe, yang mengatakan, "bahwa orang tidak boleh menutup mata pada pembalasan". Sedangkan teori gabungan yang kedua, yaitu yang menitikberatkan pada pertahanan tata tertib masyarakat. Menurut teori ini, bahwa pidana yang dijatuhkan tidak boleh lebih berat dari pada yang ditimbulkannya dan gunanya juga tidak boleh lebih besar dari pada yang seharusnya.

Dalam Rancangan KUHP Nasional, Pasal 47 diatur masalah tujuan pemidanaan, yaitu:

1) Pemidanaan bertujuan untuk:

Ke-1 mencegah dilakukannya tindak pidana dengan menegakan norma hukum demi pengayoman masyarakat.

Ke-2 memasyarakatkan terpidana dengan mengadakan pembinaan sehingga menjadikannya orang yang baik dan berguna. 
Ke-3 menyelesaikan konflik yang ditimbulkan leh tindak pidana, memulihkan keseimbangan, dan mendatangkan rasa damai dalam masyarakat.

2) Pemidanaan tidak dimaksudkan untuk menderitakan dan tidak diperkenankan merendahkan martabat manusia.

Bertolak dari ketentuan Rancangan KUHP di atas, maka dapat dikatakan bahwa substansi dalam ketentuan tersebut merupakan penjabaran dari teori gabungan dalam arti yang luas. Ia meliputi usaha prevensi, koreksi, kedamaian dalam masyarakat dan pembebasan rasa bersalah pada terpidana (mirip dengan expiation)

Dewasa ini sudah tidak ada lagi penganut teori pembalasan (absolut) yang klasik dalam arti bahwa pidana merupakan suatu keharusan demi keadilan belaka. Menurut Sudarto, kalau masih ada penganut teori pembalasan, mereka itu dikatakan sebagai teori pembalasan modern. Dari apa yang diuraikan di atas, inilah agaknya yang menjadi pertimbangan dalam konsiderans dari UndangUndang Nomor 12 Tahun 1995 Tentang Pemasyarakatan yang menyebutkan, "bahwa sistem pemasyarakatan adalah merupakan rangkaian penegakan hukum yang bertujuan agar Warga Binaan Pemasyarakatan menyadari kesalahannya, memperbaiki diri dan tidak mengulangi tindak pidana sehingga dapat diterima kembali oleh lingkungan masyarakat, dapat aktif berperan dalam pembangunan, dan dapat hidup secara wajar sebagai warga yang baik dan bertanggung jawab".

Sistem pemidanaan yang merupakan rangkaian pemidanaan dalam penegakan hukum di Indonesia harus mengenal yang namanya asas keseimbangan antara pelaku dan korban, dengan demikian perlindungan terhadap pelaku akan lebih di utamakan. Bentuk pertanggung jawaban pelaku terhadap korban tindak pidana pada kenyataannya kurang terlindungi karena tidak ada bentuk nyata perlindungan terhadap korban pelaku tindak pidana, dengan demikian orientasi sistem pemidanaan harus lebih mengutamakan bagaimana bentuk perlindungan terhadap korban.

Perlindungan hukum terhadap korban harus lebihnyata dan tidak juga untuk menderitakan pelaku tindak pidana akan tetapi dapat memenuhi kewajiban pelaku tindak pidana terhadap korbannya dalam bentuk pemberian ganti rugi baik dalam segi materil dan mempertanggungjawabkan menjalani pidana, dengan terlaksananya keseimbangan baik terhadap pelaku dan korban maka bentuk perlindungan 
terhadap korban dapat terlaksana dengan baik.

Orientasi pemidanaan yang harus diperhatikan oleh pembuat undangundang tidak hanya memikirkan bagaimana memidana tetapi juga perlindungan terhadap korban yang dapat terpenuhi dengan baik selain itu pelaku tindak pidana setelah menjalani pidana dapat berubah dan tidak melakukan hal serupa serta dapat bersosialisasi dan diterima dalam lingkungan masyarakat lagi sehingga kehidupan dalam limgkungan msysrakat aman dan damai.

\section{KESIMPULAN}

Maka dari itu pemidanaan bertujuan memperbaiki terpidana supaya menjadi anggota masyarakat yang berguna, dapat menyadari kesalahannya, dan kelak setelah melalui proses pembinaan di dalam Lembaga Pemasyarakatan dapat kembali hidup di tengah-tengah kehidupan masyarakat. Mencermati hukum pidana positif dalam hal ini harus dikaitkan dengan tujuan pemidanaan, dalam arti bahwa pemidanaan itu adalah bertujuan untuk pembalasan terhadap terpidana atau bertujuan menyingkirkan terpidana dari masyarakat supaya masyarakat aman dari ancaman perbuatan seperti yang dilakukan oleh terpidana. Oleh karena itu Orientasi pemidanaan yang harus diperhatikan oleh pembuat undang-undang tidak hanya memikirkan bagaimana memidana tetapi juga perlindungan terhadap korban yang dapat terpenuhi dengan baik selain itu pelaku tindak pidana setelah menjalani pidana dapat berubah dan tidak melakukan hal serupa serta dapat bersosialisasi dan diterima dalam lingkungan masyarakat lagi sehingga kehidupan dalam limgkungan msysrakat aman dan damai.

\section{DAFTAR BACAAN}

\section{Buku :}

Halim, A. Ridwan, Pengantar Ilmu Hukum Dalam Tanya Jawab, Ghalia Indonesia, Jakarta, 2005.

Hamzah, Andi. 1986. Sistem Pidana dan Pemidanaan Indonesia. Jakarta: Pradnya Paramita.1986.

\section{Peraturan perundang-undangan}

Undang-Undang Dasar 1945

Undang-Undang Nomor 1 Tahun 1961 Hukum Pidana

Undang-Undang Nomor 8 Tahun 1981 Hukum Acara Pidana

Undang-Undang Nomor 12 tahun 1995 Tentang Pemasyarakatan. 